\title{
Sahipsiz Hayvanlara Yönelik Van Büyükşehir Belediyesi’nin Kentteki Faaliyetlerinin Değerlendirilmesi*
}

\author{
Evaluation of the Activities of Van Metropolitan Municipality on the without Owner Animals in the \\ City
}

\author{
Vedat YILMAZ \\ Doç. Dr., Van Yüzüncü Yıl Üniversitesi, \\ İ̈B , Kamu Yönetimi Bölümü, \\ vedatyilmaz77@gmail.com \\ https://orcid.org/0000-0003-4624-9824
}

Makale Başvuru Tarihi: 15.04.2020

Makale Kabul Tarihi: 31.08.2020

Makale Türü: Araştırma Makalesi

\section{Kübra NACAR}

Yüksek Lisans Öğr., Van Yüzüncü Yıl Üniversitesi, SBE, Kaти Yönetimi A.B.D., kubrancr@gmail.com https://orcid.org/0000-0002-0089-3246

Anahtar
Kelimeler:
Büyükşehir,
Kent,
Sahipsiz
Hayvanlar,
5199 Sayılı
Kanun,

\section{ÖZET}

Günümüz toplumu her ne kadar hayvan sever olmuş olsa da bütünüyle hayvanlardan veya sahipsiz hayvanlardan şikayetçi olan insan sayısı azımsanmayacak düzeydedir. Sahipsiz hayvanlar, onların sağlıkları ile birlikte toplumun rahatlı̆̆ için kontrol altında tutulmalıdır. Böyle durumlar sahipsiz hayvanlar için tasarlanmış rehabilitasyon merkezleri, bakım evleri ve tedavi merkezleri ile gerçekleştirilebilinir. Belirtilen merkezlerin faal bir şekilde yerelde faaliyet göstermelerinde büyükşehir belediyelerinin önemi yadsinamaz. Büyükşehir belediyeleri hem insanları hayvanlardan korumak hem de hayvanları insanlardan korumak adına sahipsiz hayvanlara yönelik faaliyetlerini devam ettirmektedir. Bu çalı̧̧manın amacl; büyükşehir belediyelerinin sahipsiz hayvanlara yönelik yapmış olduğu faaliyetler hakkında bilgilendirmelerin yanında yapılan faaliyetlerin yeterliliğinin tartışılmasıdır. Bu bağlamda, 2012 yılında çıkarılan 6360 sayılı yasayla birlikte büyükşehir belediyesi olan ve Türkiye'nin en doğusunda yer alan Van Büyükşehir Belediyesi örneklem olarak alınmıştır. Çalışmada Van Büyükşsehir Belediyesinin sahipsiz hayvanlar arasında en fazla göze çarpan köpek ve kedilere yönelik yapılan faaliyetleri değerlendirilerek önerilerde bulunulacaktır.

\begin{abstract}
Although today's society has become animal lovers, the number of people who complain about animals or unattended animals is at a considerable level. Stray animals should be kept under control for the comfort of society, together with their health. Such situations can be realized with rehabilitation centres, nursing homes and treatment centres designed for unattended animals. The importance of metropolitan municipalities in the active operation of the mentioned centres locally cannot be denied. Metropolitan municipalities continue their activities towards unattended animals both to protect people from animals and to protect animals from people. The purpose of this study is to discuss the adequacy of the activities carried out in addition to informing about the activities carried out by the metropolitan municipalities towards unattended animals. IIn this context, Van municipality which has become a metropolitan municipality with the Law No. 6360, adopted in 2012, and located in the far east of Turkey, was taken as a sample. In the study, suggestions will be made by evaluating the activities of Van Metropolitan Municipality for dogs and cats, which are the most prominent among the unattended animals.
\end{abstract}

* Bu çalışma; International Asian Congress on Contemporary Sciences-IV Bildiri kitabında Yayınlanmış olan "Van Büyükşehir Belediyesinin Kentteki Sahipsiz Hayvanlar Konusundaki Faaliyetlerinin Değerlendirilmesi”, başlıklı bildirinin genişletilmiş ve güncellenmiş halidir. 


\section{GİRIş}

İnsanlar tarafindan yaşam alanları gasp edilen sahipsiz hayvanların dünyada her geçen gün sayıları artış göstermektedir. Her yıl binlerce sahipsiz hayvan farklı sebeplerden dolayı insanlar tarafından öldürülmektedir. $\mathrm{Bu}$ durumun en önemli sebebi olarak; insanların, sahipsiz hayvanların varlığını kendilerine, yakınlarına ve çevreye bir tehdit olarak görmeleri gösterilebilir. Günümüzde sokak hayvanları özellikle köpek ve kediler, belediyeler ve toplum için çözülmesi gereken önemli bir sorun olarak gösterilmektedir. Bazı insanlar için sahipsiz hayvanlar sorun olarak görülse de hayvan severlere göre; dünya sadece insanlar için değil insanlar kadar hayvanların da yaşama alanıdır. Ancak toplumun bir bölümüne göre sahipsiz hayvanların ormanlık alanlarda yaşaması gerekmektedir. Dodurka "Sokak hayvanı" kavramını; sahibi olmayan, sokakta yaşayan, sokakta doğmuş veya öncesinde sahiplenilip belirli bir süre sonunda evden atılmış hayvanlar tabiriyle tanımlamıştır (Dodurka, 2009). Genellikle kedi ve köpekler sahipleniliyor sonrasında sahibinin ölmesi ya da terk etmesi sonucunda sahipsiz kalabilmektedir. Anayasada 5199 Sayılı Hayvan Koruma Kanunu ile devletin bazı kurumlarına ve bütün vatandaşlara hayvanları koruma hakkı tanınmıştır. Bu yasayla bütün hayvanların hakları koruma altına alınmıştır. Aslında hayvanları korumak öncelikle toplumun üstlenmesi gereken bir görevdir. Fakat genel olarak insanların, sahipsiz hayvanların agresifliğine ve oluşturdukları çevre kirliliğine yönelik ön yargıların oluştuğu görülmektedir.

Hayvan sağlığı büyük ölçüde insan sağlığıyla ilişkili olduğundan hayvan ve insan ilişkileri son zamanlarda önemli bir boyut kazanmıştır. Sokak hayvanlarının sayıları artıyor ve bu durum onlar için de birçok sorunu meydana getirmektedir. Bu gibi sorunların önüne geçilmesi için özellikle büyükşehir belediyeleri tarafından ciddi önlemlerin alınması gerekmektedir. Bu noktada büyükş̧ehir belediyelerinin kanunlar ile belirlenen görev ve sorumluluklarını beklenilen düzeyde yerine getirmelidir. Türkiye'de sahipsiz hayvanların içinde bulunduğu sorunlar ve zorlu yaşam koşullarına çözüm üretmek, belirli kuruluşlar ile bağlantılı olarak yerel yönetimlerin denetimi altındadır. Büyükşehir belediyeleri sadece vatandaşlar için değil, yerel alanda bulunan her türlü sorun ve aynı zamanda canlılara karşı sorumlulukları ve görevleri yerine getirmekle yükümlüdür.

Bu çalışmada Van Büyükşehir Belediyesinin sahipsiz hayvanlara yönelik faaliyetleri dile getirilecek olup, bu bağlamda; 5199 sayılı hayvanları koruma kanunu hakkında bilgiler sunulduktan sonra Van Büyükşehir Belediyesinin sahipsiz hayvanlara yönelik faaliyetleri ele alınarak değerlendirme ve önerilerde bulunulacaktır.

\section{BÜYÜKŞEHIR BELEDIYYESİ KAVRAMI VE TARİHSEL GELİŞIMI}

Büyükşehir kavramı genel anlamda; metropolis, metropol, metropoliten gibi ifadeler ile kullanılmaktadır. Büyükşehir ya da anakent kelimesi Yunanca asıllı "metro" ve "polis" kelimelerinin birleşmesiyle oluşmuş ve ilk olarak Antik Yunan kent devletlerinin tanımlanmasında; ardından Paris, Londra, Tokyo ve New York gibi büyük yerleşim alanları için kullanılmıştır (Eke, 1985:41). Büyükşehir; diğer kentlere göre daha yoğun nüfusa sahip, etrafındaki diğer kentlerle kıyaslandığında ticari faaliyetlerin daha fazla olduğu, sanayi endüstrisi gelişmiş ve hizmet alanında belirli bir noktaya gelmiş kentlerdir (Çınar vd., 2009:37). Başka bir ifadeyle Büyükşehirler birden fazla küçük kentlerin bir araya geldiği, nüfus ile ekonomik faaliyetlerin yoğun olarak görüldüğü geniş yerleşim yerleridir (Frey ve Zimmer, 2001:26). Kent; kendine özgü özellikleri olan ve belirli bir yerleşim alanından yoğunlaşmış nüfusa sahip yerleşim şeklidir (Hout vd., 2000:14). Büyük şehiri ya da anakenti diğer kentlerden ayıran kısmı kent hizmetlerinin daha profesyonel düzeyde ve planlı bir şekilde yerel halka sunulmasıdır. Verilen bilgiler ışığında büyükşehire yönelik genel bir tanım yapmak gerekirse büyükşehir; birkaç kentin bir araya gelmesiyle sosyo-ekonomik ve kültürel faaliyetlere ilişkin olanakların daha fazla olduğu, kentlere göre sistemsel bir yapının varlığının söz konusu olduğu yerleşim alanları olarak ifade edilebilir.

Günümüzdeki anlamda büyükşehir olgusu, 18. yüzyılda başlayıp, 19. yüzyılda doruk noktasına ulaşıp, batıdaki endüstri çağıyla birlikte kırdan kentte doğru yoğun göçün yaşanması sonrası ortaya çıkmıştır (Eke, 1985:41-42). Büyükşehir, devletin uyguladığı sosyo-ekonomik politikalar sonrası oluşmuştur (Keleş, 2006:275). Türkiye'de büyükşehir belediyelerinin ortaya çıkış sürecini konolojik olarak sıralayacak olunursa; Bakanlar Kurulu Kararıyla İmar ve İskan Bakanlığına bağlı olarak 1965 yılında İstanbul, İzmir ve Ankara illerinde Nazım İmar Plan Bürolarının kurulması, 1972 yılında Bakanlıklararası İmar Koordinasyon Kurulunun oluşturulması, yine aynı tarihte (1972 yılında) yasa tasarısı olarak İçişleri Bakanlığınca hazırlanan Metropoliten Hizmet Birliği, 1975 yılında İçişleri Bakanlığı tarafından hazırlanan Metropoliten Hizmet Birliği Yasa Tasarısı, 1979 yılında Bakanlar Kurulu Kararıyla Planlama ve Eşgüdüm Kurulunun oluşturulması, 1980 yılında İçişleri Bakanlığı ile İmar ve İskan Bakanlığı tarafından hazırlanan Büyükkent Birliği Yasa Tasarısı, 1980 yılında büyük şehirlerin 
etrafındaki yerleşim alanlarının ana belediyelere bağlanması hakkındaki 2561 sayılı yasanın uygulamaya girmesi, 1982 y1lında 1982 Anayasasının 127. maddesine "Büyükşshirler için özel yönetimler ...oluşturulur", ibaresinin konulması sonrasında 1984 yılında çıkarılan 3030 sayılı yasayla Türkiye'de büyükşsehir süreci başlanmıştır (Erdumlu, 1993:48-49'dan akt.: Tekel, 2009:197).

1980 yılına gelininceye kadar büyükşehirlere ilişkin yapılan çalışmalar daha çok zorunlu olarak birlikleşme modeli çerçevesinde, uzun süreli çözümler yerine kısa süreli günü kurtarmak adına çözümler üretilmiş olması (Bulut: 1999:50), nüfustaki yoğun artış ve kaynakların yetersiz olması gibi sorunların çözümünde yetersiz kalınması, büyükşehirler için yeni bir uygulama arayışını devam ettirmiştir. 1984 yılında kabul edilen 3030 say1lı kanunla büyükşehirlerin yönetimine yönelik yeni bir uygulamaya geçilmiştir. Yeni sistem, büyükşehir belediyelerinin yönetimlerindeki hukuki statülerini düzenleyerek, sunulan hizmetlerin daha planlı, programl, etkin ve verimli bir biçimde yürütülmesi hedeflenmiştir. Uygulamaya konulan bu sistem ile sınırları dahilinde birden çok ilçe bulunan yerleşim yerleri büyükşehir olarak ifade edilmiştir. Yapılan düzenlemeyle ilk olarak Ankara, İstanbul ve İzmir illeri büyükşehir belediyesi olarak hizmet sunmaya başlamıştır.

Uygulamaya konulan 3030 sayılı yasayla büyükşehir belediyesi olabilmek için gerekli olan şartlar; yerleşim yerinin nüfusunun 300 binin üzerinde olması ve büyükşehir sınırları dahilinde birden çok ilçenin bulunmasıydı. Yasanın çıkarıldığı dönemde bu şartları sağlayan sadece Ankara, İstanbul ve İzmir illeriydi (Genç, 2014:2). 3030 sayılı kanunla İstanbul, Ankara ve İzmir'de iki kademeli belediyeler oluşturulmuştur. Bu durumda, bir yerleşim alanında büyükşehir belediyesi oluşturulması için belediyenin sınırları dahilinde birden çok ilçenin yer alması gerekmektedir. İlçenin bulunmaması durumunda ise ilk olarak merkezi yönetimce en az iki ilçenin oluşturulması öngörülmüştür (Kaypak ve Yılmaz, 2016:31). Türkiye 1984 y1lında 3030 sayılı yasayla belirtilen üç ilin büyükşehir belediyesi olarak halka hizmet sunmaya başlamasının ardından 1986 yılında Adana ili, 1987 yılında Kayseri, Konya, Gaziantep, Bursa illeri, 1993 yılında ile Antalya, Eskişehir, İzmit, Mersin, Samsun, Erzurum ve Diyarbakır illeri (504 nolu KHK) ve 2000 yılında ise Sakarya ili büyükşehir belediyesi olmuş ve 2000 yılı itibariyle ülkedeki büyükşehir belediye sayısı 16'ya yükselmiştir.

Büyükşehir belediyesi olmanın sosyo-ekonomik, siyasal, kültürel, çevresel ve psikolojik bakımdan etkileri bulunmaktadır. Bu etkilerin bir kısmı yerel halkın hayatlarında olumlu yönde gerçekleşirken bir kısmı olumsuz yönde gerçekleşmektedir. Yerel halk, yerel yönetimler arasında istek ve taleplerinin yerine getirilmesi için en fazla başvuruyu büyükşehir belediyelerine yapmaktadır (Atmaca, 2013:173; İzci ve Turan, 2013:149; Bulut ve Karakaya, 2016:3). Halkın talepleri, yaşanan gelişmeler üzerine istenilen düzeyde karşılanamamış, büyüyen büyükşehirlerde ekonomik, sosyal, demografik ve toplumsal sorunların artması üzerine etkinlik ve verimliliği artıran yeni bir yönetim ihtiyacı zorunlu hale gelmiştir (Karakılçık, 2015:174; Bulut ve Dönmez, 2019:31). 3030 sayılı yasanın büyükşehir belediyelerinin yönetimi noktasında yetersiz kalması sonrası, halkın talep ve ihtiyaçlarının daha etkin bir şekilde karşılanması amacıyla 2004 yılında 5216 sayılı büyükşehir belediyesi yasası uygulamaya geçirilmiştir. 5216 sayılı yasa günümüzde varlığını devam ettirmekte olup, zaman zaman yasada değişiklikler yapılmaktadır. Yapılan değişiklikler arasında en öne çıkan 2012 yılında çıkarılan 6360 sayılı yasadır. 5216 sayılı büyükşehir belediyesi yasasında yapılan 6360 sayılı yasa değişikliği ile birlikte 14 il (Aydın, Balıkesir, Denizli, Hatay, Kahramanmaraş, Malatya, Manisa, Mardin, Muğla, Ordu, Şanlıurfa, Tekirdağ, Trabzon, Van) daha yeni büyükşehir belediyesi olmuş ve Türkiyede'ki büyükşehir belediyesi sayıs1 30'a yükselmiştir. Türkiye'de sayısı artan büyükşehir belediyelerinin yetki ve sorumluluk alanları da genişletilmiştir. Büyükşehir belediyesinin yerel halkın talep ve isteklerini yerine getirmenin yanında sahipsiz hayvanların korunması ve barınmasına yönelik görevleri de bulunmaktadır. $\mathrm{Bu}$ konuya ilişkin bilgiler hayvanların korunmasına yönelik 5199 sayılı yasayla birlikte başlıklar halinde aşağıda sunulmuştur.

\section{5199 SAYILI HAYVANLARI KORUMA KANUNU}

5199 sayılı Kanun hayvanların; korunması, bakımı, eziyet görmemesi, sahiplenme ve hayvan haklarının korunmasına yönelik geniş bilgileri içermektedir. 5199 Sayılı Kanun'unun 2. Kısım, 1. Bölümü'nde; hayvanların korunması, bakımı ve sahiplenilmesi konularına yer verilmiştir. Bu maddede hayvanların sahiplenilmesi ve bakımına göre; hayvanı sahiplenen şahıs veya şahıslar, hayvanın çeşidine ve üreme yöntemine uygun ihtiyaçlarını karşılamak, sağlığına ve çevreye dikkat etmekle yükümlüdür. Şahıslar sahiplenmiş oldukları hayvanlardan kaynaklı çevre kirliliğine ve insanlara karşı hayvanların verebileceği zararlara karşı tedbirler almak zorundadır. Ev ve süs hayvanı satışı yapan şahısların, yerel yönetimlerden hayvanların bakımı konusunda gerekli olan sertifikaları almaları gerekmektedir. Hayvanları üreten işletmeler ya da sahiplenen şahıslar yavruları tehlikeye atmamak suretiyle gerekli olan tüm tedbirleri almalıdır. Ev ve süs hayvanları arasında doğada yaşamaya elverişli olmayanlar terk edilemezler. Yalnızca başka şahıslar tarafından yeniden 
sahiplendirilebilirler. Bu maddede yer alan sahipsiz ve güçten düşmüş hayvanların korunması konusuna göre; güçten düşmüş hayvanlar 3285 sayılı Hayvan Sağlığı Zabıtası Kanunu'na en uygun şekilde uygulama yapılır. Güçten düşmüş hayvanlar kesinlikle ticari amaçlı kullanılamaz (binicilik vs). Yerel yönetimler sahipsiz ve güçten düşmüş hayvanlara yönelik gerekli olan önlemleri alır. Güçten düşmüş ve sahipsiz hayvanlar en kısa sürede yerel yönetimlere bağlı ilgili kurumlara teslim edilir. Tedavi için bulundukları ortamdan alınan hayvanların tedavi süreci tamamlandıktan sonra alındıkları ortama geri bırakılması zorunludur.

5199 Sayılı Kanun'unun 2. Kısım, 2. Bölümü'nde; hayvanlara nasıl müdahale edileceği konusuna açık bir şekilde yer verilmiş olup; hayvanlara cerrahi müdahaleleri veterinerler dışında hiç kimsenin yapamayacağı, kontrolsüz üremeyi durdurmak adına kısırlaştırma yapılabilineceği, ev ve süs hayvanının dış görünüşünü değiştirmek maksadıyla kuyruk ve kulak kesilmesi gibi fiziksel cerrahi müdahale yapılmasının yasak olduğu konularına yer verilmiştir. Bu konularla birlikte hayvanlar üzerinde deney yapılması da yasaklanmıştır. Hayvan deneyi yapan kurum ve kuruluşlar için ilgili deneylerin yapılması konusunda etik kuruldan izin alınması koşulu bulunmaktadır. Hayvanların yaşamlarını sürdürdükleri sürece organları alınamaz ya da dokuları parçalanamaz. Kendi doğalarına ters düşecek biçimde hormon ya da ilaç verilmesi yasaklanmıştır. Bu maddede hayvan deneyleri hususuna göre; Bilimsel olmayan tanı ve tedavide deney hayvanı olarak kullanılamazlar. Uygun biçimde deneyde kullanılacak hayvanlarında en doğru yöntemlerle kullanılması gerekmekte ve sonrasındaki bakımı esas alınmaktadır. Deney hayvanlarının bulundurulması, üremesi konularındaki işletmelerin ve personellerin uyacağı kurallar Tarım ve Orman Bakanlığı tarafından belirlenmektedir.

5199 Sayılı Kanun'unun 2. Kısım, üçüncü ve dördüncü bölümlerinde; hayvanların ticareti ve eğitilmesine dair görevler ve hayvanların kesimi, öldürülmesi ve yasaklanması hususularına yer verilmiştir. Bu maddede hayvan ticareti konusunda; hayvanlar satılırken sağlıklarının iyi olması gerektiği, barınacakları yerin koşullara uygun olmas1 gerektiği, hasta ya da sakat olan hayvanların usulüne uygun olacak şekilde olsa bile kesilmelerinin veya acı çekmemesi amacıyla öldürülmelerinin açıkça yasak olduğu belirtilmiştir. Çiftlik hayvanlarının bakımı konusunda Tarım ve Orman Bakanlığı tarafından gerekli olan düzenlemeler yapılmıştır. Hayvanlar ticari maksatla film veya reklam çekimlerinde kullanılabilir. Ancak bunun için ilgili yönetmelikte yer alan koşulların sağlanması gerekmektedir. Sakat ve hasta hayvanların satılması ya da sahiplendirilmesi yasaklanmıştır. Bu maddede eğitim konusuna yer verilmiş olup; hayvanların gücünü aşacak şekilde ve hayvanı yaralayacak yöntemler ile eğitilemez. Hayvanların farklı canlılar ile dövüştürülmesine izin verilmez. Fakat geleneksel gösteriler ilgili Bakanlıklardan izin alınarak düzenlenebilir. Ev ve süs hayvanı satan kişiler, bu hayvanların bakımı ve korunması ile ilgili olarak yerel yönetimler tarafından düzenlenen eğitim programlarına katılarak sertifika almaları gerekmektedir. Dördüncü Bölümde bazı yasaklara yer verilmiş olup; hayvanlara bilinçli olarak zarar verici biçimde davranmak, canlarını incitmek, psikolojik olarak baskı yapmak, hayvanları güçlerinin yetmediği işleri yaptırmak, hayvan bakımından anlamayan kişilere hayvan satmak, 16 yaşından küçük olanlara ev hayvanı satmak, hayvanın ölümü gerçekleşmeden vücuduna müdahale etmek, hayvanlarla cinsel ilişkide bulunmak, hayvanlara işkence etmek, hayvanlara zorla yemek yedirmek, Pitbull Terrier gibi tehlikeli hayvanları beslemek, barındırmak ve satışını yapmanın yasak olduğu belirtilmiştir.

5199 Sayılı Kanun'unun 3. Kısmında hayvan koruma yönetimine yer verilmiştir. Üçüncü Kısım Birinci Bölüm'ünde; Mahalli Hayvan Koruma Kurulları Teşkilât, Görev ve Sorumlulukları belirtilmiş olup, "Her ilde il hayvanları koruma kurulu, valinin başkanlığında, sadece hayvanların korunması ve mevcut sorunlar ile çözzümlerine yönelik olmak üzere toplanır", hükmüne yer verilmiştir. Bu toplantılara; Büyükşehir belediyesi olan illerde büyükşehir belediye başkanları, büyükşehire bağlı ilçe belediye başkanları, büyükşehir olmayan illerde belediye başkanları, il çevre ve orman müdürü, il tarım müdürü, il sağl1k müdürü, il milli eğitim müdürü, il müftüsü, belediyelerin veteriner işleri müdürü, veteriner fakülteleri olan yerlerde fakülte temsilcisi, münhasıran hayvanları koruma ile ilgili faaliyet gösteren gönüllü kuruluşlardan valilik takdiri ile seçilecek en çok iki temsilci, il veya bölge veteriner hekimler odasından bir temsilcinin katılacağı belirtilmiştir. Bölümün devamında, her ilde valinin başkanlığında hayvanları koruma kurulunun olması gerektiği ve bu kurulun sadece hayvanların korunması kapsamında sorunlarla bu sorunların çözümüne yönelik toplanması gerektiği konusuna yer verilmiş olup,

"Il hayvan koruma kurulunun çalışma esas ve usulleri Bakanlıkça çıkarılacak yönetmelikle belirlenir. Il sinırları içinde hayvanların korunmasina ilişkin sorunları belirleyip, koruma sorunlarının çözüm tekliflerini içeren yıllık, beş yıllık ve on yıllık plân ve projeler yapmak, yıllık hedef raporları hazırlayıp Bakanlığın uygun görüşüne sunmak, Bakanlığın olumlu görüşünü alarak hayvanların korunması amacıyla her türlü önlemi almakla yükümlüdürler",

şeklinde ifade edilmiştir. 5199 Sayılı Kanun'unun 3. Kısım, 2. Bölüm'ünde; Denetim ve Hayvan Koruma Gönüllüleri başlığına yer verilmiştir. Bu madde de; 


\begin{abstract}
"Denetim elemanlarınin nitelikleri ve denetime ilişkin usul ve esaslar ile kaylt ve izleme sistemi kurma, bildirim yükümlülüğ̈̈ ile bunları verecekler hakkindaki usul ve esaslar Bakanlıkça çıkarılacak yönetmelikle belirlenir. Yerel hayvan koruma görevlileri; bölge ve mahallerindeki, öncelikle köpekler ve kediler olmak üzere, sahipsiz hayvanların bakımları, aşılarının yapılması, aşıll hayvanların markalanması ve kayıtlarının tutulmasının sağlanması, kısırlaştırılması, saldırgan olanların eğitilmesi ve sahiplendirilmelerinin yapılması için yerel yönetimler tarafindan kurulan hayvan bakımevlerine gönderilmesi gibi yapılan tüm faaliyetleri yerel yönetimler ile eşgüdümlü olarak yaparlar",
\end{abstract}

hükmü yer almaktadır. İlgili madde ile denetim mekanizması oluşturulmuş ve hayvanların haklarının korunmasına yönelik yerel yönetimler ile eşgüdümlü bir şekilde faaliyetlerin yürütülmesi konuları ele alınmıştır. Kanun'un 3. Kısım 3. Bölümü; hayvanların korunmasının mali açıdan desteklenmesi üzerine olup, sahipsiz hayvanların bakım evlerinde bakılmaları için bakım evlerinin kurulması, tedavilerinin yapılması için hayvan hastanelerinin oluşturulması noktasında yerel yönetimler öncelikli olmak üzere kuruluşlara bakanlık tarafından maddi destek sağlanır.

5199 Sayılı Kanun'unun üçüncü kısım, dördüncü bölümü; “Diğer Hükümler” başlı̆ğ altındadır. Bu bölümde; eğitici yayınlar, trafik kazaları, hayvanat bahçeleri, yasak ve izinler, koruma altına alma, vd. konularına yer verilmiştir. Hayvanların korunması ve rahat bir ortamda yaşamlarını sürdürmeleri için eğitici programların yapılması ihtiyacı, radyo ve televizyonlarda yaygın bir şekilde yayınlanması gerektiğinden, bir hayvana çarpan ya da kaza ile zarar veren kimsenin hayvanı en yakın veterinere ya da tedavi ünitesine götürmesinin zorunlu olduğu, hayvanat bahçelerinin doğal ortama en uygun şekilde yapılmış olması gerektiği, hayvan bulunduran kişilerin hayvanlara zarar vermesi sonucunda denetlenmesi ve hayvanlara el konulması konularına yer verilmiş̧tir.

5199 Sayılı Kanun'unun Dördüncü Kısım (Cezai Hükümler), Birinci Bölümü’nde; idari para cezası verme yetkisi, cezalar, ödeme süresi, tahsil ve itiraz konuları yer almıştır. Hayvanları koruma kanunu kapsamında 2020 yılına ait idari para cezalarına ilişkin bilgiler aşağıdaki tablo 1'de sunulmuştur. 5199 Sayılı Kanun'unun 5. Kısım, 1. Bölüm'ünde; "Çeşitli Giderici ve Son Hükümler” yer almış olup, "Bu Kanunda, ceza hükmü altına alınmış fiillerin tekrarı halinde para cezaları bir kat, daha fazla tekrarı halinde üç kat artırılarak verilir", ibaresi ile hayvan hakları koruma altına alınmaya çalışılmıştır.

Genel olarak 5199 sayılı yasa değerlendirildiğinde; hayvanlara iyi ve uygun bir şekilde davranılması, uygun bir alanda barınmalarının sağlanması, onlara eziyet çektirilmemesi, hayvanların bakımları, tedavi edilmeleri, hayvanlara zarar verilmemeleri kısaca hayvan haklarının korunmasına yönelik önemli tedbirleri bünyesinde barındırmaktadır. Kanuna aykırı davranış sergileyen kişilere yine kanunda belirtilen cezai yaptırımlar uygulanmaktadır. Aşağıdaki tablo 1'de 5199 sayılı Hayvanları Koruma Kanunu'nun 28 inci maddesinde yer alan 2020 yılına ait uygulanan para cezası miktarlarına ilişkin bilgilere yer verilmiştir.

Tablo 1. 5199 Sayılı Hayvanları Koruma Kanunu Kapsamında 2020 Yı1ı İdari Para Ceza Miktarları

\begin{tabular}{|c|c|}
\hline CEZANIN MAHIYETİ & $\begin{array}{l}\text { İDARİ PARA } \\
\text { CEZASI }\end{array}$ \\
\hline $\begin{array}{l}5199 \text { sayılı yasanın } 4 . \text { maddesi (k) bendinin ikinci fikrasında yer alan “...söz konusu hayvanlarını } \\
\text { yavrulatmak isteyenler, doğacak yavruları belediyece kayıt altına aldırarak bakmakla velveya dağıtımını } \\
\text { yapmakla yükümlüdür." Hükmüne aykırı davranışta bulunanlara hayvan başına, }\end{array}$ & 947 TL \\
\hline $\begin{array}{l}\text { Yasanın 5. maddesinin birinci fikrası "Bir hayvanı, bakımının gerektirdiği yaygın eğitim programına katılarak } \\
\text { sahiplenen veya ona bakan kişi, hayvanı barındırmak, hayvanın türüne ve üreme yöntemine uygun olan } \\
\text { etolojik ihtiyaçlarını temin etmek, sağlığına dikkat etmek, insan, hayvan ve çevre sağlığı açısından gerekli tüm } \\
\text { önlemleri almakla yükümlüdür", ikinci fikras1 "Hayvan sahipleri, sahip oldukları hayvanlardan kaynaklanan } \\
\text { çevre kirliliğini ve insanlara verilebilecek zarar ve rahatsızlıkları önleyici tedbirleri almakla yükümlü olup; } \\
\text { zamanında ve yeterli seviyede tedbir alınmamasından kaynaklanan zararları tazmin etmek zorundadırlar.", } \\
\text { üçüncü fikrası "Ev ve süs hayvanı satan kişiler, bu hayvanların bakımı ve korunması ile ilgili olarak yerel } \\
\text { yönetimler tarafından düzenlenen eğitim programlarına katılarak sertifika almakla yükümlüdürler".) ve } \\
\text { altıncı cümlede yer alan "Ev ve süs hayvanlarının üretimini ve ticaretini yapanlar, hayvanları sahiplenen ve } \\
\text { onu üretmek için seçenler annenin ve yavrularının sağlığın tehlikeye atmamak için gerekli anatomik, } \\
\text { fizyolojik ve davranıs karakteristikleri ile ilgili önlemleri almakla yükümlüdür.", fikralarında öngörülen } \\
\text { hayvanların sahiplenilmesi ve bakımı ile ilgili yasaklara ve yükümlülüklere uymayan ve alınması gereken } \\
\text { önlemleri almayanlara hayvan başına, }\end{array}$ & $181 \mathrm{TL}$ \\
\hline
\end{tabular}


Yasanın 5. maddesinin yedinci fikrasında yer alan "Ev ve süs hayvanlarl ile kontrollü hayvanlardan, doğal yaşama ortamlarına tekrar uyum sağlayamayacak durumda olanlar terk edilemez; beslenemeyeceği ve iklimine uyum sağlayamayacağı ortama bırakılamaz. Ancak, yeniden sahiplendirme yapılabilir ya da hayvan 628 TL bakımevlerine teslim edilebilir.", hükümlerini yerine getirmeyen kişilere hayvan başına,

Yasanın 6. maddesinin birinci fikrasıda yer alan "Sahipsiz ya da güçten düşmüş hayvanların, 3285 sayılı Hayvan Sağlı̆̆ Zabıtası Kanununda öngörülen durumlar dışında öldürülmeleri yasaktır”, hükmüne aykırı davranan kişilere hayvan başına,

Yasanın 7. maddesinde yer alan "hayvanlara tıbbi ve cerrahi müdahaleler sadece veteriner hekimler tarafindan yapılır..." hükümlerine aykırı hareket edenlere hayvan başına,

$1.902 \mathrm{TL}$

Yasanın 8. maddesinin birinci fikrasında yer alan "Bir hayvan neslini yok edecek her türlü müdahale yasaktır, " hükmüne aykırı davranışta bulunanlara hayvan başına,

$628 \mathrm{TL}$

Yasanın 8. maddesinin ikinci fikrasında yer alan "Hayvanların, yaşadıkları sürece, tıbbî amaçlar dışında organ veya dokularının tümü ya da bir bölümü çıkarllıp alınamaz veya tahrip edilemez." Hükmü, üçüncü fikrasında "Ev ve süs hayvanının dış görünüşünü değiştirmeye yönelik veya diğer tedavi edici olmayan kuyruk ve kulak kesilmesi, ses tellerinin alınması ve tırnak ve dişlerinin sökülmesine yönelik cerrahi müdahale yapılması yasaktır." Hükmü ve dördüncü fikrasında yer alan "Bir hayvana tıbbî amaçlar dışında, onun türüne ve etolojik özelliklerine aykırl hale getirecek şekilde ve dozda hormon ve ilaç vermek, çeșitli maddelerle doping yapmak, hayvanların türlerine has davranış ve fizikî özelliklerini yapay yöntemlerle değiştirmek yasaktır” hükümlerine aykırı davranışta bulunan kişilere hayvan başına,

Yasann 9. maddesi ve çıkarılacak olan yönetmeliklerde belirtilen "Hayvan Deneyleri" konularına uymayanlara hayvan başına,

Yasanın 9. Maddesine uymayarak yetkisi olmadığı halde hayvan deneyi yapanlara hayvan başına

947 TL

Yasanın 10. Maddesinde yer alan "hayvan ticareti izni almayanlara ve bu konudaki yasaklara ve yönetmelik hükümlerine” aykırı davranan kişilere,

31.903 TL

Yasanın 11. maddesinin birinci fikrasında yer alan "Hayvanlar, doğal kapasitesini veya gücünü aşacak şekilde veya yaralanmasına, gereksiz acı çekmesine, kötü alışkanlıklara özendirilmesine neden olacak yöntemlerle eğitilemez. " Hükmüne aykırı hareket eden kişilere,

Yasanın 11. maddesinin ikinci fikrasında yer alan "Hayvanları başka bir canlı hayvanla dövüştürmek yasaktır. ” Hükmüne aykırı davranan kişilere hayvan başına,

3.820 TL

Yasanın 12. maddesinin birinci fikrasında yer alan "Hayvanların kesilmesi; dini kuralların gerektirdiği özel koşullar dikkate alınarak hayvanı korkutmadan, ürkütmeden, en az acı verecek şekilde, hijyenik kurallara uyularak ve usulüne uygun olarak bir anda yapılır. Hayvanların kesiminin ehliyetli kişilerce yapılması sağlanır. " Hükmüne aykırı hareket edenlere hayvan başına,

Yasanın 12. maddesinin 2.fikrasıda yer alan "Dini amaçla kurban kesmek isteyenlerin kurbanlarını dini hükümlere, sağllk şartlarına, çevre temizliğine uygun olarak, hayvana en az acı verecek şekilde bir anda kesimi, kesim yerleri, ehliyetli kesim yapacak kişiler ve ilgili diğer hususlar Bakanlık, kurum ve kuruluşların görüşü alınarak, Diyanet İşleri Bașkanlığının bağlı olduğu Bakanlıkça çıkarılacak yönetmelikle belirlenir." Hükmüne aykırı harekette bulunan kişilere hayvan başına,

Yasanın 13. maddesinin 1. fikrasında yer alan "Kanuni istisnalar ile tıbbi ve bilimsel gerekçeler ve glda amaçlı olmayan, insan ve çevre sağllğına yönelen önlenemez tehditler bulunan acil durumlar dişında yavrulama, gebelik ve süt anneliği dönemlerinde hayvanlar öldürülemez." hükümlerine aykırı hareketlerde bulunan kişilere öldürülen hayvan başına,

Yasanın 13. Maddesinin 2. fikrasında yer alan "Öldürme işleminden sorumlu kişi ve kuruluşlar, hayvanın kesin olarak öldüğ̈̈nden emin olunduktan sonra, hayvanın ölüsünü usulüne uygun olarak bertaraf etmek veya ettirmekle yükümlüdürler. 'hükümlerine aykırı davranan işletmelere öldürülen hayvan başına,

3.820 TL

3.180 TL

Yasanın 14. maddesi (a): Hayvanlara kasıtlı olarak kötü davranmak, acımasız ve zalimce işlem yapmak, dövmek, aç ve susuz bırakmak, aşırı soğuğa ve sıcağa maruz bırakmak, bakımlarını ihmal etmek, fiziksel ve psikolojik acı çektirmek.

(b): Hayvanları, gücünü aştı̆̆ açıkça görülen fiillere zorlamak.

(c): Hayvan bakımı eğitimi almamış kişilerce ev ve süs hayvanı satmak.

(d): Ev ve süs hayvanlarını onaltı yaşından küçüklere satmak.

(e): Hayvanların kesin olarak öldügü anlaşılmadan, vücutlarına müdahalelerde bulunmak.

947 TL

(g): Kesim için yetiştirilmiş hayvanlar dışındaki hayvanları ödül, ikramiye ya da prim olarak dağıtmak.

1.902 TL

(h): Tıbbî gerekçeler hariç hayvanlara ya da onların ana karnındaki yavrularına veya havyar üretimi hariç yumurtalarına zarar verebilecek sunî müdahaleler yapmak, yabancı maddeler vermek.

(1): Hayvanları hasta, gebelik süresinin 2/3'ünü tamamlamış gebe ve yeni ana iken çalıştırmak, uygun olmayan koşullarda barındırmak.

(j): Hayvanlarla cinsel ilişside bulunmak, işkence yapmak.

4.776 TL

4.776 TL

1.902 TL

4.776 TL

$4.776 \mathrm{TL}$

.


YILMAZ, Vedat ve NACAR, Kübra - Sahipsiz Hayvanlara Yönelik Van Büyükşehir Belediyesi'nin Kentteki Faaliyetlerinin Değerlendirilmesi

(k): Sağllk nedenleri ile gerekli olmadıkça bir hayvana zor kullanarak yem yedirmek, acl, istırap ya da zarar veren yiyecekler ile alkollü içki, sigara, uyuşturucu ve bunun gibi bă̆ımlılık yapan yiyecek veya içecekler vermek.

Bentlerine aykııı bir şekilde davranan kişilere,

Yasanın 14. maddesinin f bendi; Kesim hayvanları ve 4915 sayıl Kanun çerçevesinde avlanmasına ve özel üretim çiftliklerinde kesim hayvanı olarak üretimine izin verilen av hayvanları ile ticarete konu yabani hayvanlar dıșlndaki hayvanlarl, et ihtiyacı amacıyla kesip ya da öldürüp piyasaya sürmek. I bendi; Pitbull Terrier, Japanese Tosa gibi tehlike arz eden hayvanlarl üretmek; sahiplendirilmesini, ülkemize girişini, satışını ve reklamını yapmak; takas etmek, sergilemek ve hediye etmek. Bentlerine aykırı davranan kişilere hayvan başına,

RTÜK'ün takibi sonucunda yasanın 20. maddesinde yer alan "Hayvanların korunması ve refahı amactyla; yaygın ve örgün eğitime yönelik programların yapılmasl, radyo ve televizyon programlarında bu konuya yer verilmesi esastır. Türkiye Radyo ve Televizyon Kurumu ile özel televizyon kanallarına ait televizyon programlarında ayda en az iki saat, özel radyo kanallarının programlarında ise ayda en az yarım saat eğitici yayınların yapılması zorunludur. Bu yayınların \% 20'sinin izlenme ve dinlenme oranı en yüksek saatlerde yapılması esastır. Radyo ve Televizyon Üst Kurulu görev alanına giren hususlarda bu maddenin takibi ile yükümlüdür." Hükümlerine aykırı hareket ettiği tespit edilen ulusal radyo ve televizyon kurum ve kuruluşlarına maddenin ihlal edilmiş olduğu her ay için,

Yasanın 21. maddesinde yer alan "Bir hayvana çarpan ve ona zarar veren sürücü, onu en yakın veteriner hekim ya da tedavi ünitesine götürmek veya götürülmesini sağlamak zorundadır.” Hükmüne aykırı davranan kişilere hayvan başına,

Yasanın 22. maddesinde yer alan "İşletme sahipleri ve belediyeler hayvanat bahçelerini, doğal yaşama ortamına en uygun şekilde tanzim etmekle ve ettirmekle yükümlüdürler. " Hükmüne uymayanlara, hayvanat bahçelerinde kötü şartlarda barındırdıkları hayvan başına,

Kaynak: www.mevzuat.gov.tr; http://jandarmaforum.com (E.T.: 03.02.2020).

Tablo incelendiğinde; 5199 sayılı yasa ile öngörülen yaptırımlar; hayvanların kayıt altına alınması, hayvanların bakımı ve sahiplenilmesinde uyulması gereken kurallar, güçten düşmüş hayvanların öldürülmesinin önlenmesi, veteriner hekimler haricinde hayvanlara cerrahi müdehalenin yapılmaması, herhangi bir hayvanın neslinin yok olmasının önlenmesi, hayvanlara acı çektirilmesi, hayvanların döğüştürülmesi, hayvanların organlarının alınması, hayvanlara kötü alışkanlık kazandırılmasının önlenmesi, hayvanların ölmeleri halinde usulüne uygun bir şekilde bertaraf edilmesi, hayvanlara acımasız bir şekilde vurulmasının önlenmesi, hayvanlara eziyet çektirmek, aç ya da susuz bırakmak, sogukta ya da sıcakta bırakmak, bakımlarının ihmal edilmesi, hayvanlar ile cinsel ilişkide bulunulması, işkence yapılması, hayvanlara uyuşturucu mahiyetindeki yiyecek ve içeçeklerin verilmesi, televizyon kanallarında ayda en az 2 saat, radyo kanallarında ise en az 30 dakika eğitici yayınların yapılması zorunluluğunun olması, hayvanların korunması ve hayvanların yaşamlarını rahat bir şekilde sürdürmeleri konularında caydırıcı özellikler taşımaktadır.

Günümüzde insanların birçoğu hayvanlara çarptıktan sonra onları ölüme terk etmektedir. Yapılan bu davranıșında yasal olarak yasak olduğu ve para cezasının da $(947 \mathrm{TL})$ olduğunun farkında değildir. Bu bakımdan insanların bilgilendirilmesi nasıl ki bir insan kaza geçirdiğinde hemen en yakın sağlık kuruluşuna kaldırılıyorsa hayvanın da bir canı olduğu ve kurtarılması gerektiği bilincinin yaygınlaştırılması gerekmektedir. Bu noktada yerel ve merkezi yönetim koordineli bir şekilde faaliyetlerini artırmalıdır. Özellikle yaşadığımız bu günlerdeki pandemi (Covid 19) sürecinde hayvanların beslenme ihtiyaçlarının giderilmesi önem arz etmektedir.

\section{SAHIPSIZZ HAYVAN GEÇICI BAKIM EVİ VE REHABİLITASYON MERKEZİ}

Sahipsiz hayvanlar sokaklara her ne kadar alışmış olsalar da mevsim değişikliğinden ya da insanların tepkisinden dolayı farklı birçok sorunla karşı karşıya kalmaktadır. Ev ortamına alışmış hayvanlarsa dışarıdaki yaşam ortamlarında hayatlarını sürdürmekte zorlanıyor ve hasta olma, aç kalma, şiddet görme benzerindeki birçok sorunla karşı karşıya kalabilmektedir. Bütün bu belirtilen olumsuzluklara karşın her zaman ilgiye muhtaç bir şekilde yaşamlarını devam ettirmaktedirler. İnsanların sahipsiz hayvanları sahiplenme konusunda istenilen duyarlılığı göstermemeleri sahipsiz hayvanların yaşamlarını zorlaştırmaktadır. Yerel yönetim birimleri sahipsiz hayvanların aşırı bir sayıda olması ve özellikle yeni hayvanların kırsal kesimde yaşayan insanlar tarafından merkeze bırakılmasından dolayı sahipsiz hayvanların kontrolü noktasında sorunlar yaşamaktadır. Bütün bu koşullar içerisinde özellikle belediye ve büyükşehir belediyeleri sahipsiz hayvanların korunması bakımı ve rehabilite edilmesine yönelik faaliyetler yürütmektedir.

Rehabilitasyon süreci; toplama (hayvanların bulundukları yerden alınması süreci), aşılama (bulundukları yerden alınan hayvanların gerekli olan aşı işlemlerinin yapılması süreci), kısırlaştırma (hayvanların 
çoğalmasını control altına almak amacıyla yapılan tıbbi müdehaledir), İşaretleme (hayvanların birbirinden ayırt edilmesi için yapılan işlemdir), Geri bırakma (toplanan hayvanların gerekli işlemri tamamlanması sonrası alınan yaşam ortamına yeniden bırakılmasıdır) şeklinde gerçekleşmektedir.

Sahipsiz hayvanların toplanması için toplama ekibi kurulmaktadır. Toplama ekibinde yer alan kişiler eğitimli olup usulüne uygun bir şekilde hayvanlara zarar vermeden görevlerini yerine getirmeye çalışmaktadır. Yeterli bilgi ve eğitime sahip olmayan kişiler uzman veterinerler tarafindan eğitime tabi tutulur. Toplama sırasında yalnızca hayvanların saldırgan olması durumunda sakinleştirici ek müdahalede bulunulabilir. Aksi bir durum söz konusu olmadıkça normal koşullarda toplama işlemi gerçekleştirilir. Toplanan hayvanlar aşılama, ve kısırlaştırmanın yanında herhangi bir hastalıklarının olması durumunda tedavileri için bakım evlerine getirilmektedir. Bakım evine getirilen hayvanların gerekli olan kontrol işlemleri yapılarak hayvanların kısırlaştırılması ve aşıları yapılır.

5199 Sayılı Hayvanları Koruma Kanunu'nun yedinci maddesinde yer alan "Hayvanlara tıbbî ve cerrahi müdahaleler sadece veteriner hekimler tarafindan yapılır", hükmü doğrultusunda hayvanlara gerekli olan tıbbi ve cerrahi müdehalelerde deneyimsiz olan kişilerin müdahale etmelerinin önüne geçilmiştir. Sahipsiz hayvanların bakım evinde tedavi edilmeleri için yeterli donanıma sahip olması gerekmektedir. Hayvanlar bakımevlerinde iyileşme durumlarına göre farklılık gösterebilmektedir. Bu bakımdan hayvan bakımevlerinin yeterli kapasiteye sahip olunması önem arz etmektedir. Çünkü sahipsiz hayvan yoğunluğu fazla olan yerleşim alanlarında aynı anda fazla sayıda hayvan gelmesi durumunda sorunlar oluşacaktır. Yalnızca kısırlaştırma ve aşılama yapılan hayvanların bakım evinde 2 gün süre ile tutulduğu düşünüldüğünden uzun süreli tedaviye ihtiyaç duyulan hayvanların bakımı için bakımevlerinin kapasitesi önem arz etmektedir.

Bakımevinde tedavisi yapılan sahipsiz hayvanlar için gerekli olan duyurular yapılır, duyuru yapıldıktan sonra sahiplendirilemeyen hayvanlar ikinci günden itibaren kayıt altına alınıp, müdahale edildiğine ilişkin işaretlemeler yapılarak toplandıkları alanlara yeniden bırakılırlar. Özellikle sahipsiz hayvanların toplandıkları alanlara yeniden bırakılmaları önemli bir konudur. Çünkü 5199 Sayılı Hayvanları Koruma Kanunu'nda sahipsiz hayvanların ormanlara ya da 1 ssız alanlara, yaban hayatı yaşam alanlarına bırakılmaması gerektiği öngörülmüştür. 5199 Sayılı Hayvanları Koruma Kanunu kapsamında belediyeler, sokak hayvanlarını toplayıp, kısırlaştırılıp hatta bütün yapılması gereken tedavilerini yapıp sonrasında toplandıkları alanlara geri bırakmasına yönelik görevleri bulunmaktadır.

Günümüz koşullarında hala hayvan bakım evlerine sahip olmayan ilçeler ve iller var olmaktadır. Bu olumsuz durumun yanı sıra bakım evlerine sahip olan pek çok ilde ve ilçede yeterli ve uygun olanaklar sağlanmamaktadır. Bunun birinci sebebi belediyelerin sokak hayvanlarını değersiz görmüş olması, ikinci sebebi ise belediyelerin düşük bütçesinin olmasıdır. Böyle sorunların olduğu bölgelerde hayvansever gönüllülerine önemli görevler düşmektedir (Demir Erol, 2018:73).

Türkiye'nin en büyük sahipsiz hayvan bakımevi ve rehabilitasyon merkezi 2018 yılında Antalya ilinin Alanya ilçesinde açılmıştır. 24 dönümlük alana kurulu olan hayvan bakımevi ve rehabilitasyon merkezi 5 ana binadan oluşmakta olup, 1 kedi ünitesi, 2 köpek bakımevi, 1 hayvan bakım ünitesi ve 1 adet klinik üniteyle birlikte merkezde karantina, hasta bakım, yavrulu anne, hayvan müşahede, yabani hayvan bölümleri ile muayene, ameliyat odası, gıda ve soğuk hava depoları yer almaktadır (www.haberler.com, 2020). Alanya'da kurulan Hayvan Bakımevi ve Rehabilitasyon Merkezi Türkiye'de örnek bir bakımevi olarak faaliyetlerini yürütmektedir. Yerleşim alanlarındaki hayvanların yoğunluklarına göre belirlenen kapasitelerde sahipsiz hayvan bakımevi ve rehabilitasyon merkezlerinin oluşturulması, varolanların mevcut durumlarının gözden geçirilmesi önem arzetmektedir. Bu noktada merkezi yönetim ile birlikte yerel yönetimlere önemli görevler düşmektedir. Aşağıda örneklem olarak alınan Van büyükşehir belediyesinin sahipsiz hayvanlara yönelik faaliyetlerine yer verilmiştir.

\section{VAN BÜYÜKŞEHİR BELEDIYYESINIIN SAHİPSIZ HAYVANLARA YÖNELİK FAALIYYETLERİ}

Genel olarak dünyada yüz milyonun üzerinde sahibi olmayan kedi ve yaklaşık 200 milyon köpek bulunmaktadır. Doğan her on köpekten yalnız bir tanesi yuva edinebilmektedir. Yılda yaklaşık olarak iki milyon yedi yüz bin kedi ve köpek insanlar tarafından öldürülmektedir. Sahipsiz hayvanların korunması, barınması ve onları sahiplenecek insan sayısının yeterli miktarda olmaması sorunu yaşanmaktadır (https://sahipsizhayvanlar.org/, 2020). Bu noktada görülen eksikliği gidermek adına büyükşehir belediyeleri son yıllarda etkin bir şekilde hizmet sunmaya çalışmaktadır (Koç ve Ayvazoğlu Demir, 2019:29).

Hizmet sunumunda büyükşehir belediyeleri; bilgi ve iletişim teknolojilerini kullanarak isnenilen amaca kısa sürede ulaşır ve olumsuz durumların düzeltilmesi noktasında önemli kararlar alması kolaylaşır, halkın ihtiyaç 
duyduğu mal ve hizmetler doğru olarak belirlenir (Atmaca ve Yılmaz, 2019:407; Belli ve Aydın, 2017:411; Erdoğan, 2019:51). Sunulacak hizmetin türü, kapsamı, içeriği, sınırları, en uygun sure ve araçlar ile sunulması için belediyenin kamuoyunu tanıma ve hizmet sunumunu tanıtma aracı olan kurumsal web sayfası, interaktif modüller ve mobil uygulamaları kullanılır (Mecek, 2017:1816-1818; Mecek, 2018:2317-2318). Böylelikle yönetimsel anlamda alınan kararların daha geniş platformlara, daha kısa sürede iletilmesi ve geri dönüş alınması sağlanır. Büyükşehir belediyeleri sunmak istediği hizmetlerin kalitesini artırmak, toplumsal beklentilerin değerlendirilmesi ve çözümü noktasında öncelik sırası oluşturulurken kısa veya uzun vadeli, operatif ya da stratejik, rutin veya rutin olmayan, bireysel ya da kurul halinde bir çok kararlar almaktadır (Eren ve Yılmaz, 2018:520; Kaypak, vd., 2017:1802).

Alınan kararlara vatandaşlar dijital ortamda ulaşır ve vatandaşın büyükşehir belediyesi tarafından alınan kararlara katılımı önemli düzeyde sağlanır. Bu doğrultuda sahipsiz hayvanların sahiplendirilmesi noktasında dijital platformlardan önemli düzeyde faydalanmak gerekmektedir. Büyükşehir belediyelerinin sahipsiz hayvanlara yönelik faaliyetlerini konu alan bu çalışmada, Van Büyükşehir Belediyesi örneklem olarak alınmıştır. Van Büyükşehir Belediyesi 2012 yılında çıkarılan 6360 sayıl1 "14 İlde Büyükşsehir Belediyesi ve 27 Illçe Kurulması ile Bazı Kanun ve Kanun Hükmünde Kararnamelerde Değişiklik Yapılmasına Dair Kanun" ile büyükşehir belediyesi olmuş ve 30 Mart 2014 yılında yapılan yerel seçimler sonrası yerel halka hizmet sunmaya başlamıştır (Yılmaz, 2018:4368).

5199 Sayılı Hayvan Koruma Kanunu ile bütün hayvanların hakları koruma altına alınmıştır. Bu doğrultuda diğer büyükşehir belediyelerde olduğu gibi Van Büyükşehir Belediyesinde de sahipsiz hayvanların korunmasına yönelik faaliyetler yürütülmektedir. Van Büyükşehir Belediyesi yetkilileri ile yapılan görüşmeler sonras1 sahipsiz hayvanlara yönelik yapılan ve yapılması planlanan faaliyetler genel olarak şunlardır;

- Van Büyükşehir Belediyesine bağlı 6.500 metre kare açık alan, 3.550 metre kare kapalı alan olmak üzere toplam 10.500 metre karelik alana sahip sahipsiz Geçici Hayvan Bakım ve Rehabilitasyon Merkezi'nin bulunduğu, merkezin birçok sahipsiz hayvana ev sahipliği yapmakta olduğu, hayvanların refahı için önemli faaliyetlerin gerçekleştirildiği,

- Geçici Hayvan Bakım ve Rehabilitasyon Merkezinin, Büyükşehir Sağlık İşleri Daire Başkanlığı bünyesindeki Hayvan Sağlığı ve Koruma Şube Müdürlüğüne bağlı olarak faaliyetlerini yürüttüğü,

- Geçici Hayvan Bakım ve Rehabilitasyon Merkezinin kapasitesinin 400 olduğu içerisinde hayvan muayene, ameliyathane, yoğun bakım ünitesi, tıraş, aşılama ve banyo odaları ile cihazların bulunduğu;

- Hayvan Bakım ve Rehabilitasyon Merkezinde 7 gün 24 saat hizmet sunulduğu,

- Rehabilitasyon merkezinde sahipsiz hayvanların gerekli olan tedavileri, kısırlaştırma, küpe takma, cilt, iç-dış parazit ve kuduz aşılarının yapıldığı, agresif olan hayvanlara yönelik rehabilitee işlemlerinin yapıldı $\breve{1} 1$,

- Sahipsiz hayvanlara yönelik yapılan işlemrin 5199 sayılı yasanın içeriğine uygun bir şekilde yapıldığı,

- Büyükşehir belediyesi sahipsiz hayvanlar konusunda önemli faaliyetler gerçekleştirme çabası içerisinde olduğu, mobil veteriner aracının kullanıldığı, mobil veteriner aracının (vetkabin) bütün ilçelere bakım ve rehabilitasyon hizmeti sunduğu,

- Mobil kısırlaştırma aracı ile ilçelere gidilerek kısırlaştırma işlemlerinin yerinde yapılarak hayvanların kendi yaşam alanlarına yeniden bırakıldığı, Hasta olan hayvana bulunduğu yerde ya da ilçe belediyelerinin barınak veya bakım merkezlerinde müdahalelerin yapıldığı,

- Büyükşehire ait sahipsiz hayvanların beslenmesi için besleme araçlarının olduğu, belediye tarafından şehir merkezinde 45 adet mama odak yerinin oluşturulduğu ve bu sayının artırılacağ 1 , belirlenmiş olan odak yerlerine beslenme aracı ile düzenli olarak mama ve su bırakıldı̆̆ı, özellikle yaşanan pandemi sürecinde (covid 19) bırakılan mama miktarının artırıldığı, yine sahipsiz hayvanların beslenmesi için belirlenen noktaların düzenli olarak kontrol edildiği bırakılan mamaların azalması ya da bitmesi durumunda takviye mamaların konulduğu,

- Sahipsiz hayvanlar için veterinelik hizmetlerinin sunulduğu, veterinerlik Hizmetlerinin içerisinde; sahipsiz hayvanların üremelerinin kontrol edilmesi, şüpheli hayvanların karantina altına alınması, sahipsiz hayvanların kayıt altına alınması, şikayet ve taleplerin değerlendirilmesi, bulaşıcı hastalıklar kapsamında tedbirlerin alınması, rehabilitasyon merkezi ve bakım evine gilen her ziyaretçi ile özel olarak ilgilenilmesi, ziyaretçilere hayvan bakımı konusunda küçük çaplı eğitimlerin verildiği, 
- Hayvanların ağız ve diş hastalalıklarının tedavi edilmesine yönelik DentiVet hizmeti sunulduğu, bu doğrultuda hayvanların ağız ve diş hastalıklarına müdehale edilmesi için diş ünitesinin oluşturulduğu,

- Kedi ve köpeklerin bulaşıcı dış hastalıklar ve deri enfeksiyonlarından korunmasına yönelik DuşPed hizmetinin verildiği, DuşPet hizmetinde sahipli ya da sahipsiz hayvanların şampuanla yıkanması, durulanması, tüy kremi uygulanması, parazitleri önleyici solüsyon püskürtülmesi sonrası kurulama işlemlerinin yapıldığı ve bu süreçte hayvanların incitilmediği,

- Geçici Hayvan Bakım ve Rehabilitasyon Merkezi'nde sahiplendirme biriminin bulunduğu, bu birimde bulunan sahipsiz hayvanlardan tedavisi bitmiş sağlıklı olanların sahiplendirildiği ve sahipsiz hayvanların tamamının ücretsiz bir şekilde sahiplendirildiği,

- Gönüllü olarak hayvan sahiplenme konusunda yardım almak isteyen vatandaşlara Hayvan Bakım ve Rehabilitasyon Merkezinde ilgili bilgilendirmelerin yapıldı $\breve{g} 1$;

- Geçici Hayvan Bakım ve Rehabilitasyon Merkezi tarafından sokak hayvanları için yapılan bütün bakımlar, aşı, ilaç gibi ihtiyaç malzemeleri ücretsiz olarak sunulduğu, ayrıca sahipsiz hayvanların sahiplendirilmesi konusunda Van Büyükșehir Belediyesi Hayvan Bakım Evi ve Rehabilitasyon Merkezinin instagram hesabının aktif olarak kullanıldığı, buradan gelen taleplerin dikkate alınarak değerlendirmelerin yapıldı ̆̆ 1 ,

- Şehirde bulunan sahipsiz hayvanların genel olarak kontrol altında olduğu ancak kırsal kesimde yaşayan insanların merkeze geldiklerinde beraberinde bir kaç köpek ya da kedi bırakması sonrası kontrolün zorlaştı̆̆ 1 belirtilmiştir.

Yapılan gözlemler sonrası; Van Büyükşehir Belediyesi tarafından sahipsiz hayvanların barınması, tedavilerinin yapılması ve beslenmeleri için mama, ilaç gibi gerekli ihtiyaç malzemelerine yönelik maddi harcamalardan kaçınmadığı, en önemli ve göze çarpan özelliği ise hayvanlara karşı duyarlı olunması ve sevgiyle yaklaşılması konusunda taviz verilmemesidir. Ayrıca Hayvan Bakım ve Rehabilitasyon Merkezinin temizliğine özen gösterildiği çalışan personelin kibar ve nezaket kuralları çerçevesinde yaklaşımlarının olduğu, hayvanlara severek ve istekli bir şekilde bakıldığı gözlemlenmiştir.

Genel olarak Van büyükşehir belediyesinin sahipsiz hayvanlara yönelik yapmış olduğu faaliyetlerin önemli düzeyde olduğu ancak hala sokaklarda başıboş sahipsiz kayıt altına alınmamış hayvanlara rastlanması, özellikle sahipsiz köpeklerin insanlara saldırmaları konularındaki şikayetlerin önüne tam anlamıyla geçilememiş̧ olması, Van Yüzüncü Y1l Üniveristesi kampüs alanı gibi belirli yerleşim alanlarında aşırı sayıda sahipsiz köpeklerin bulunması ve köpeklerin insanlara zarar verme ve insanlarında köpeklere zarar verme sorunlarının önüne hala istenilen düzeyde geçilememiş olması büyükşehir belediyesi tarafından yapılan önemli faaliyetlere gölge düşürmektedir.

\section{SONUÇ}

Günümüzde, kentleşme süreciyle beraber sahipsiz hayvanların yaşadığı alanlara müdehale edilerek kısıtlandığı, beslenme sorunları yaşadıkları, vatandaş sağlığı ve çevre sağlığı bakımından sorunların artış gösterdiği görülmektedir. Sahipsiz hayvanlar hakkında bilgilerin az ve sınırlı olduğu ve bu konuda yapılan çalışmaların yeterli seviyeye ulaşmadığı açıktır. Sahipsiz hayvanlar hem hayvanlar açısından hem de insanlar açısından önemli bir sorun olarak kendini göstermektedir. Sahipsiz hayvanların ve insanların zarar görmemesi için mutlak suretle koruma altına alınması gerekmektedir. Ancak günümüz koşullarında hala hayvanların korunmasına yönelik hayvan bakım evlerine sahip olmayan kent olarak tabir edilen yerleşim yerlerinin olduğu görülmektedir. $\mathrm{Bu}$ olumsuz durumunla birlikte bakım evlerine sahip olan pek çok il ve ilçe bulunmakta ancak bu yerleşim alanların da da yeterli ve uygun olanaklar sunulamayabilmektedir. Bu durumun nedenleri olarak belediyelerin sokak hayvanlarını değersiz görmüş olabilmeleri ya da belediyelerin düşük bütçesinin olması olarak gösterilebilir. Sahipsiz hayvanlar ile ilgili sorunlar büyük kentlerde kendini daha fazla göstermektedir.

Van Büyükşehir Belediyesinin sahipsiz hayvanlara yönelik yapmış olduğu faaliyetleri temel alan bu çalışmada yetkililer ile yapılan görüşme ve gözlem sonrası; Van Büyükşehir Belediyesinde sahipsiz hayvanların korunması, bakımı ve tedavi edilmeleri için Geçici Hayvan Bakım ve Rehabilitasyon Merkezinin bulunduğu, merkezde hayvanların toplanıldığı, kısırlaştırma işlemlerinin yapıldığı, düzenli olarak aşılarının yapılarak, tedavi edilmesi gereken hayvanların tedavilerinin yapıldığı, mobil hizmet aracı ile ilçelerde bulunan hayvanlarında toplanarak belirtilen işlemlerin yapılması ardından aynı yaşam alanlarına bırakıldıkları, merkezde çalışan personelin hayvanlara şevkatli ve arzulu bir şekilde baktıkları, 45 adet kent merkezinde hayvanların 
beslenmelerinin sağlanması için odak yerlerin olduğu ve düzenli olarak bu yerlere mama ve su bırakıldığı, özellikle pandemi sürecinde bırakılan mama miktarının önemli düzeyde artırıldığı, gönüllü olarak hayvan sahiplenme konusunda yardım almak isteyen vatandaşlara ilgili bilgilendirmelerin yapıldı̆̆ı; yine geçici hayvan bakım ve rehabilitasyon merkezinde sahiplendirme biriminin bulunduğu, bu birimde bulunan sahipsiz hayvanlardan tedavisi bitmiş sağlıklı olanların sahiplendirildiği ve hayvanların sahiplenilmesi sürecinde herhangi bir ücret alınmadığı, sahiplenme sonrasında da sokak hayvanları için yapılan bütün bakımlar, aşı, ilaç gibi ihtiyaç malzemeleri ücretsiz olarak sunulduğu, sahipsiz hayvanların sahiplendirilmesi konusunda instagram hesabının aktif olarak kullanıldığı, buradan gelen taleplerle ilgili değerlendirmelerin yapıldığı, kent merkezinde bulunan sahipsiz hayvanların genel olarak kayıtlı ve kontrol altında olduğu ancak kırsal kesimde yaşayan insanların merkeze gelirken beraberinde bir kaç köpek ya da kedi getirerek kent merkezi yakınına bırakılması sonrası kontrolün zorlaştığı bilgilerine ulaşılmıştır.

Van ilinde tam donanıma sahip bir hayvan hastanesi bulunmamaktadır. Sadece Van Yüzüncü Yıl Üniversitesi Veterinerlik Fakültesine bağlı hayvan hastanesi bulunmaktadır. Burası da sahipsiz hayvanların ihtiyacını tam olarak karşılayacak düzeyde değildir. Van Büyükşehir Belediyesine bağlı yüksek kapasiteli bir hayvan hastanesinin yapılması, geçici hayvan bakım ve rehabilitasyon merkezinin kapasitesinin genişletilmesi ya da hayvan refahı ile hayvanların fiziksel ve ruhsal olanaklarının daha fazla ön plana alındığı yeni bir geçici hayvan bakım ve rehabilitasyon merkezinin oluşturulması hayvanların daha nezih bir ortamda bulunmaları, korunması, kayıt altına alınması, aşılama ve tedavilerinin yapılması sürecine önemli düzeyde katkı sunacaktır.

Sahipsiz hayvanlar sorununun temelinde çözülebilinmesi için hayvan sahiplenilmesi sorununun öncelikli olarak çözülmesi gerekmektedir. Bu sebeple Van Büyükşehir Belediyesi tarafından sahipsiz hayvanların insanlar tarafından sahiplenmesine yönelik teşvik edici eylemlerin gerçekleştirilmesi gerekmektedir. $\mathrm{Bu}$ noktada büyükşehir belediyesinin web sayfasında ya da farklı sosyal platformlarda paylaşılarak hayvan sahiplenilmesi sayıları artırılabilir. Hayvan sahiplenilmesinin yanında hayvanların beslenmeleri ve bakımlarına yönelik yardımda bulunmak isteyen hayvan severlerin bu platformalarda bir araya getirilerek yardımları alınabilir. Hayvanların korunması yönünde gönüllülük esastır. Bu doğrultuda da gönüllü olarak hayvanların korunmasına yönelik yapılan faaliyetlere bireylerinde katılması önem arz etmektedir.

Bu noktada özellikle sahipsiz hayvanların sahiplendirilmesi adına büyükşehir belediyesi tarafından yerel halkın özendirilmesine yönelik faaliyetlerin artırılması gerekmektedir. Halkı teşvik edici sahiplenilen hayvanın barınma ihtiyacının sahiplenen kişi tarafından karşılanması beslenmesi noktasında yardımda bulunulması hatta hayvan sahiplenen kişilerin su faturalarında belirli miktarda indirim yapılması gibi farklı teşvik edici yollar ile sahipsiz hayvanları sahiplenen kişi sayısı artırılabilir. Ayrıca büyükşehir belediyesi tarafından özellikle sahipsiz köpeklerin tesbiti düzenli bir şekilde yapılmalı ve kontrol altına alınmalıdır. Bu halde, kontrol altına alınan köpeklerin hem insanlara zarar vermesi, hem de insanların köpeklere zarar vermesi sorunlarının önüne büyük ölçüde geçilecektir.

Son olarak Van büyükşehir belediyesinin hayvanların korunmasına yönelik dış paydaşlar olan Van Yüzüncü Y11 Üniversitesi, Sivil Toplum Kuruluşları, kamu kurum ve kuruluş temsilcileri ile koordineli bir şekilde çalışarak hayvanların sahiplenilmesi ve korunması konularına yönelik fikir alışverişinin pandemi sürecinde online pandemi sonrasında ise yüz yüze yapılması sonrası sahipsiz hayvanlar konusunda yaşanan sorunların önemli düzeyde azalacağı düşünülmektedir.

\section{KAYNAKÇA}

ATMACA, Yıldız (2013), “Optimal Belediye Büyüklüğ̈̈ ve Yeni Büyükşehir Belediye Yasası”, Çankırı Karatekin Üniversitesi İktisadi ve İdari Bilimler Fakültesi Dergisi, S.3(2), ss.168-185.

ATMACA, Yıldız ve YILMAZ, Vedat (2019), "Digitalised Local Management and Participatory Municipalism: Çankiri Municipality Case", Theory and Practice in Social Sciences (Ed. Viliyan Krystev, Recep Efe, Emin Atasoy), St. Kliment Ohridski University Press, Sofia, ss.403-417.

BELLI, Aziz ve AYDIN, Abdullah (2017), "6360 Sayılı Kanun ve Yerelde Merkezileşme”, The Journal of Academic Social Science (JASSS), S.2(55), ss.401-413.

BULUT, Yakup (1999), “Büyük Şehir Yönetimine Kentsel Alt Örgütlenmelerin (STK ve Mahalle...) Katılımı (Gaziantep Büyük Şehir Belediyesi Örneği)”, Yayınlanmamış Doktora Tezi, Marmara Üniversitesi Sosyal Bilimler Enstitüsü, İstanbul. 
BULUT, Yakup ve DÖNMEZ, Demet (2019), "6360 Sayll Düzenlemeyle Oluşan Büyükşehir Modelinde Büyükşehir Belediyesi ile İlçe Belediyeleri ArasındaYaşanan Sorunlar ve Çözüm Önerileri: Hatay İli Örneği ”, Uluslararası Yönetim Akademisi Dergisi, S.2(1), ss.29-40.

BULUT, Yakup ve KARAKAYA, Sedat (2016), "Yerel Yöneticilerin Büyükssehir Algısı”, Mustafa Kemal Üniversitesi İktisadi ve İdari Bilimler Fakültesi Dergisi, S.1(1), ss.1-36.

ÇINAR, Tayfun, DURU, Bülent, ÇİNER, Can Umut ve ZENGİN, Ozan (2009), Büyükşehir Yönetimi Bütünleştirme Süreci, Türkiye ve Orta Doğu Amme İdaresi Enstitüsü Yayını, Ankara.

DEMIR EROL, Esra (2018), "Sokak Hayvanları ve Hayvan Bakım Evleri”, Ayrıntı Dergisi, S.5(59), ss.69-73.

DODURKA, Tamer (2009), “Köpeklerde Popülasyon Yönetimi”, E-Makale, http://www.turkvet.biz/yazi/hayvan_refah.htm (Erişim Tarihi: 30.01.2020).

EKE, Ali Erkan (1985), “Anakent Yönetimi ve Yönetimlerarası Ilişskiler: Batı Deneyimi ve Türkiye”, Amme İdaresi Dergisi, S.18(4), ss.41-62.

ERDOĞAN, Oğuzhan (2020), "Yerel Politikaların Şekillenmesinde Dijital Demokrasi Uygulaması Olarak Antalya Muratpaşa Belediyesi Komşu Meclisi”, Uluslararası Yönetim Akademisi Dergisi, S.3(1), ss.48-60.

ERDUMLU, Güngör (1993), Büyükşsehir Belediyeleri Araştırması, DPT Yayınları, Ankara.

EREN, Veysel ve YILMAZ, Vedat (2018), "Büyükşehir Belediye Yönetiminde Karar Alma Sürecinde Etkinlik ve Verimlilik Problemi: Hatay Örneği”, İnternational of Academic Value Studies, S.4(19), ss.518-533.

FREY, William H. ve ZACHARY, Zimmer (2001), "Defining the City", Handbook of Urban Studies (Ed. Ronan Paddison), Sage Publications, London (UK), ss.14-35.

GENÇ, Fatma Neval (2014), “6360 Sayılı Kanun ve Aydın'a Etkileri”, Adnan Menderes Üniversitesi Sosyal Bilimler Enstitüsü Dergisi, S.1(Özel Say1), ss.1-29.

HOUT, Jean Louis, THALMANN, Jean Paul ve VALBELLE, Dominique (2000), Kentlerin Doğuşu (Çev. Ali Bektaş Girgin), İmge Kitabevi, Ankara.

İZCI, Ferit ve TURAN, A. Menaf (2013), “Türkiye'de Büyükşehir Belediyesi Sistemi ve 6360 Sayll Yasa ile Büyükşehir Belediyesi Sisteminde Meydana Gelen Değişimler: Van Örneği”, Süleyman Demirel Üniversitesi İktisadi ve İdari Bilimler Fakültesi Dergisi, S.18(1), ss.117-152.

KARAKILÇIK, Yusuf (2015), Yeni Yerel Bölgesel Gelişmeler Işı̆̆ında Yerel Yönetimler, Seçkin Yayıncılık, Ankara, 2. Bask1.

KAYPAK, Şafak ve YILMAZ, Vedat (2016), “Hatay Büyükşehir Yapılanma Sonrasında Çevre Sorunlarına Yaklaşım ve Çevre Düzenlemeleri”, Bitlis Eren Üniversitesi Sosyal Bilimler Enstitüsü Dergisi, S.5(1), ss.25-50.

KAYPAK, Şafak, YILMAZ, Vedat ve BİMAY, Muzaffer (2017), “Dijital Çağda Yerel Yönetimler”, Süleyman Demirel Üniversitesi İktisadi ve İdari Bilimler Dergisi, S.22(Kayfor’15 Özel Say1s1), ss.1798-1813.

KELEŞ, Ruşen (2006), Yerinden Yönetim ve Siyaset, Cem Yayınevi, İstanbul, 5. Bask1.

KOÇ, Aysun ve AYVAZOĞLU DEMİ, Pınar (2019), "Geçici Hayvan Barınaklarının Genel Durumları ve Sorunlarına İlişkin Bir Değerlendirme: Ege Bölgesi Örneği”, MAE Veterinerlik Fakültesi Dergisi, S.4(1), ss.29-33.

MECEK, Mehmet (2017), "E-Devlet ve E-Belediye: Kavramsal Çerçeve ve Türkiye'de Belediye Web Sitelerine Yönelik Yapılan Çalışmaların Değerlendirilmesi”, Süleyman Demirel Üniversitesi İktisadi ve İdari Bilimler Fakültesi Dergisi, S.22(KAYFOR15 Özel Say1s1), ss.1815-1851.

MECEK, Mehmet (2018), "E-Belediyecilik, Halkla Ilişkiler, Bilgi Edinme, Şeffaflık vb. Unsurlar Açısından Belediye Web Sayfalarının Kullanılması ve Etkinlik Analizi: Bolvadin Belediyesi Örneği”, Bolvadin Araştırmaları (Ed. Mustafa Güler, Cantürk Kayahan), Eğitim Yayınevi, Konya, Cilt.1, ss.2307-2350. 
TEKEL, Ayşe (2009), “Türkiye'de Metropoliten Alan Yönetiminden Metropoliten Yönetişime Geçiş: Ankara Örneğinde Bir Değerlendirme", Selçuk Üniversitesi İktisadi ve İdari Bilimler Fakültesi Sosyal ve Ekonomik Araştırmalar Dergisi, S.18, ss.191-214.

YILMAZ, Vedat (2018), "6360 Sayılı Yasa ile Uygulamaya Konulan Büyükşehir Modelinin Yerel Halka Yansimalart: Hatay, Malatya, Manisa ve Van Belediyesi", Journal of Social and Humanities Sciences, S.5(30), ss.4364-4378.

5199 sayılı Hayvanları Koruma Kanunu (01.07.2004 tarih ve 25509 sayılı Resmi Gazete).

5216 say1lı Büyükşehir Belediye Kanunu (23.07.2004 tarih ve 25531 say1lı Resmi Gazete).

6360 sayılı On Dört İlde Büyükşehir Belediyesi ve Yirmi Yedi İlçe Kurulmasi ile Bazi Kanun ve Kanun Hükmünde Kararnamelerde Değişiklik Yapilmasina Dair Kanunu (06.12.2012 tarih ve 28489 sayılı Resmi Gazete).

http://jandarmaforum.com/tr/viewtopic.php?f=7\&t=2700 (Erişim Tarihi: 22.06.2020).

https://sahipsizhayvanlar.org/ Erişim Tarihi: 24.02.2020).

https://www.haberler.com/turkiye-nin-en-buyuk-hayvan-bakimevi-acildi-10916667-haberi/ (Erişim Tarihi: 22.06.2020). 